\title{
PSYCHOLOGICAL FACTORS OF SECOND LANGUAGE ACQUISITION ON CASE OF ETHNIC MINORITIES OF GEORGIA
}

\author{
Ia Aptarashvili, Mzia Tsereteli \\ Tbilisi State University, Tbilisi, Georgia \\ E-mail: ia.aptarashvili@tsu.ge,mzia.tsereteli@tsu.ge
}

\begin{abstract}
The purpose of the presented research is to determine the relations between success or failure in second language acquisition on one hand and personal - social factors and attitudes of an individual on the other. Besides, to define what is the predictive value of personal or social features and the attitudes of the given individual for reaching high competency in the second language. 374 schoolchildren (165 boys and 202 girls) from three regional non-Georgian schools were administered with the questionnaire consisted of several blocks: Parents' attitude to second language acquisition; Motivation; Anxiety related to the second language usage; Anxiety in class; Sense of self-confidence in the process of the Second language acquisition. The best predictors for success in SLA are: General interest in the foreign languages, parents' involvement in learning process, instrumental motivation and self-confidence in the process of language acquisition. The study has implication for foreign language teachers and experts of bilingual educations.
\end{abstract}

Key words: academic achievement, instrumental motivation, second language, self-confidence, SLA.

\section{Theoretical Framework of the Research}

Almost every next man in modern society knows at least two languages as a result of their everyday common conditions or professional work. Language is the main instrument of socialization and integration of an individual in the social-cultural spheres (Firth \& Wagner, 1997). Nowadays the problem of bilingualism and multilingual education is very essential and diverse. Different aspects of it have been studied and are at present being studied for several years by many scientists (Gardner, 1979; 1985; Lambert, 1974; 1979; 1981; Baker, 2006; Ervin \& Osgood, 1954; Weinreich, 1953; Imedadze \& Tuite, 1992 and at). One of the most important research questions is what factors influence on the successful acquisition of the second language? Scientists have different viewpoints about which ones from numerous groups of factors are more important and weighty in the sense of second language acquisition (Martos, 2006). According to what factor is emphasized and considered essential as carrying high predictive value in the process of second language acquisition, there are several models explaining the reasons of success or failure in that process. What these models have in common is that they emphasize individual-psychological factors. However, each of these models chooses one factor as leading factor defining successful behavior.

The professor of McGill University W. Lambert has been studying this problem for several years. According his model, the main factor in successful acquisition of the second language is motivation, which in its turn conditions development of identity (Identitätsentwicklung) in the second/ foreign language learning process (Lambert, 1974; 1979; 1981). Lambert distinguishes two kinds of motivation: motivation of integration and instrumental motivation (Lambert, 1981). In his opinion, motivation for integration is stronger and more important than instrumental motivation, as it has long-term, sustained, stable goals.

The second important model is R.C. Gardner's Social-Educational Model (Gardner, 1979; 1985), which partially shares the essence of the Lambert's model but in addition, he reviews the influence 
of the social-cultural environment in the second language acquisition context. The cultural and social environment in which the individual exists determines his attitudes and perceptions of other Volume 5, 2013 cultures and languages; in its turn, those perceptions have an effect on success or failure in language acquisition (Gardner, 1979; 1985). Gardner exemplifies the monoculture countries (Great Britain) where the population may consider it useless to study other languages, and consider minor groups of other language speakers obliged to study the dominant language and culture and get assimilated. He distinguishes 4 main variables influencing the quality of second language acquisition. They are as follows: Intelligence, Skill (talent) in languages, Motivation, Fear of the concrete situation of language using. The influence of each of those variables may be different according the different cultural-social environment (Gardner, 1985; Lalonde, \& Gardner, 1984).

The Clément's social context model emphasizes the importance of the social-cultural environment even more. To his opinion relation between fear of assimilation and motivation for integration determines the motivation for acquiring the second language and its result. If the fear of assimilation prevails, the motivation for acquiring the second language is lower and the result is less effective; but if motivation for integration prevails, than the motivation for acquiring the second language is high and correspondingly the result is effective (Aellen \& Lambert, 1969).

He speaks also about such variable as self-confidence. As Clément himself says, self-confidence includes anxiety as an affective aspect and self-evaluation concerning language-competence, as a cognitive aspect. Clément and his followers determined that indicators of self-confidence are correlated with indicators of the second language competence (level of acquisition) (Clement, Dorney \& Noels 1994; Gardner \& Smith, 1977, 1980; Clément \& Crudenier, 1985).

Social-cognitive model by Muller unites the models by Lambert, Gardner and Clément.

According Mueller, success in studying the second language in the formal, namely, school environment may depend on two variables: Talent (talent for language acquisition and general intellect) and School language concept. In this model the most important variable is the pupil's language self-concept. „language self-concept of the pupil“" - self-confidence, self-trusting (Selbstvertrauen) - this is the trust in one's own language skills, as Muller calls it - language self-program which is the result of long accumulation of the experience. Accurate self-evaluation of the own skills in language, which is founded namely on this basis, expresses the pupil's achievements more exactly (Müller \& Dittman-Domenichini, 2008). This construct resembles that of Clément's but in fact is quite different. Muller's construct contains Clément's construct of self-confidence and in addition - his own language self-program -motivation for language studying.

\section{Problem of Research}

The goal of the presented research is to investigate the relations between the success in second language acquisition and personal-social factors of an individual, and defining, what are the predictive values of personal or social characteristics of the given individual and his attitudes with regard to the high competence in second language acquisition.

Specific predictions of the study were the following:

(1) If parents' attitude to Georgian language and their involvement in the language learning process has predictive value with regard to successful acquisition of the second language, then it follows that the high is parents involvement in Georgian language acquisition process the higher must be student's marks in Georgian language performance, and correspondingly, the higher is his language competence.

(2) If instrumental motivation of an individual has predictive value for successful second language acquisition, then it follows that the stronger is this kind of motivation, the better are the pupil's grades in Georgian language and correspondingly, the higher is his language competence.

(3) If the pupil's self-trusting, self-confidence has predictive value for second language acquisition, then it follows that the greater is the sense of self-confidence the higher are grades in Georgian and correspondingly, the higher is his language competence.

(4) If the language anxiety of the pupil (the situational fear of the second language usage) 
OF PSYCHOLOGY

IN THE $21^{\text {st }}$ CENTURY Volume 5, 2013

has predictive value for successful acquisition of the language, then it follows that the lower is the indicator of anxiety, the higher grades he has in Georgian language and the higher is his language competence.

\section{Methodology of Research}

\section{Participants}

374 schoolchildren from three regional non-Georgian public schools participated in the research. Sample description:

- Gender of the participants: 165 participants (45\%) were male and $202(55 \%)$ were female;

- Age of the participants: Consequent to the research goal we were interested in specific aspects of studying Georgian as the second language in the formal learning environment (namely in a school environment). The age of the students was determined from the beginning. The research work has been carried out among the students of the XI and XII grades, so; correspondingly, the age of participants was between 16 and 18. Though, the statistical analysis of the results shows that among the students of the XI and XII forms were some children aged 15 or $19.37 \%$ of the inquired schoolchildren were 16 years old, $46,6 \%-17$; $13,5 \%-18 ; 2,1 \%-19$; and $0.7 \%$ - 15 years old.

- Region: The research work covered three regions: Shida Kartli (Marneuli, Sadakhlo), Samtskhe-Javakheti (Akhalcikhe, Vale, Tskruti), and Tbilisi. 4, $6 \%$ of the inquired (92 students) were from Shida Kartli; 26, 42\% (98 students) from Samtskhe-Javakheti and 49, 2\% (184 students)-from Tbilisi.

- Nationality: Majority of the inquired schoolchildren were Armenians (58, 3\%); 25, 8\% Azerbaijanians; 12, 1\% - Georgians, 2, 4\% - Russians, and among the rest 1, $4 \%$ there are Jews, Kurds and Ossetians.

- Family language: for the $42.5 \%$ of the participants the family language is Armenian, for $21.9 \%$ Azerbaijanian, for $16,7 \%$ - Russian, for $7.4 \%$ Georgian and for the rest $11,5 \%$ - it is the mix of Armenian-Russian, Azerbaiajanian-Russian Armenian-Georgian, AzerbaijanianGeorgian and so on.

\section{Instrument and Procedures}

The students filled in the questionnaire in the classroom individually. They were briefed, including the information about the goal of the research and the guidelines how to answer the questions. The guidelines for filling in the questionnaire were given also on the questionnaire sheet, at the beginning. As soon as the students finished with their answers, we began interviewing the teachers of Georgian.

\section{Research Tool}

The students were administered with the questionnaire consisted of several blocks: demographic information about the student, Attitude to the Georgian people, Attitude to the Georgian language, Integration orientation, Instrumental orientation (Gardner, 1985). Parents' involvement into the process of second language acquisition, anxiety in class, Situational fear of using the language (Clément, Dorney \& Noels 1994), Evaluation of the Georgian lesson, evaluation of the teacher of Georgian and Self-confidence.

To define the level of skillfulness in Georgian as the second language for each participant, we used a pupil's yearly assessment marks in this subject. At present, we do not have any general test for checking skillfulness according the following fundamental aspects: writing, reading, listening, and speaking. Skillfulness in the language assumes certain competencies in all of the mentioned aspects. It was significant to consider these aspects, so we have developed a questionnaire to interview the teachers. Teachers conducted students assessment in Georgian using the range of scores 0-10, likewise 
the marks of the academic performance in writing, reading, listening, speaking or in other words, a

pupil's knowledge was evaluated by 5 scores: 1 score as a yearly academic mark and 4 scores- allocated one for each skill. Based on these scores we defined the final summing score, which assessed student's competence in the Georgian language.

\section{Results of Research}

- Study results showed that the significant predictor for the high competence in the second language acquisition is the General interest in the foreign languages $\left(\mathrm{R}_{A D J}^{2}=0.143, \mathrm{~F}\right.$ $(1,373)=13.105, \mathrm{p}=0.000)$, specifically, I wish I could speak another language perfectly $(B$ $=0.125, \mathrm{p}=0.000)$; Studying a foreign language is an enjoyable experience $(\beta=0.362$, $\mathrm{p}=0.000$ ).

- Parents' attitude to Georgian language acquisition was also predictor for students' success in the language acquisition process $\left(\mathrm{R}_{A D J}^{2}=0.073, \mathrm{~F}(5,374)=3.797, \mathrm{p}=0.001\right)$, specifically, parents' good knowledge of Georgian language $(\beta=0.247, \mathrm{p}=0.000)$; Parents' often talk about the fact that knowledge of the Georgian language is the basic foundation for success in life ( $\beta=0.252, p=0.000)$; Parents' interest in the outcome of the Georgian language lessons $(\beta=0.311, \mathrm{p}=0.000)$ and parents' help in doing lessons $(\beta=0.091, \mathrm{p}=0.000)$.

- Another significant predictor for success is instrumental motivation $\left(\mathrm{R}_{A D J}^{2}=0.228, \mathrm{~F}(6,373)\right.$ $=1.952, \mathrm{p}=0.05)$, specifically, knowledge of the Georgian language, as a necessary condition for passing the high school $(\beta=0.210, p=0.000)$; Georgian, as a means of establishing relations with the Georgians $(B=0.125, p=0.03)$; Georgian as a necessary requirement to find a good job ( $(\beta=0.160, p=0.000)$; Knowledge of the Georgian language as a means to gain more respect from the society $(\beta=0.091, \mathrm{p}=0.000)$.

- The factor how the students assess their abilities in the process of learning a second language $(\mathrm{R} 2 \mathrm{ADJ}=0.360, \mathrm{~F}(9,372)=1.897, \mathrm{p}=0.000)$, was a significant predictor for success in SlA: In comparison with my classmates a can learn Georgian better $(\beta=0.222, \mathrm{p}=0.001)$; I think that I will never be able to learn the Georgian language well $(\beta=-0.183, p=0.000)$; Learning the languages isn't a problem for me $(\beta=0.224, p=0.000)$.

- The factors of Anxiety related to the second language usage $\left(\mathrm{R}_{A D J}^{2}=0.199, \mathrm{~F}(11,374)=12.583\right.$, $\mathrm{p}=0.000$ ) were also significant predictors for success in Georgian language acquisition: specifically, speaking Georgian make me nervous any time $(\beta=-0.286, \mathrm{p}=0.000)$; I am nervous, when I am asked something in Georgian ( $(\beta=-0.543, p=0.005)$; I refrain from speaking Georgian because I may become funny $(\beta=-0.422, p=0.005)$.

\section{Discussion}

As can be seen from the data analysis, the results of the research proved all sub-hypothesis. The following factors: parents involvement in the process of second language acquisition of the child, instrumental motivation, self-confidence in the process of second language acquisition have predictive value for success in Second language acquisition.

The Fact that the Instrumental motivation is good predictor for the mentioned population is natural, because the Georgian language is the state (nation) language and for ethnic minorities it is an instrument for fulfilling their future plans: most of them see their future career through learning at Georgian Universities (majority of interesting programs and courses are not available in the languages of ethnical minorities) and correspondingly, they will have to compete with Georgian candidates at the entrance exams.

Also, we can tell same about the factor "parents' involvement". In our study parents' involvement in the learning process is equally significant and this factor has predictive value for SLA. If the Parents are more concerned about explaining the importance of the Georgian language skills, if they talk with the children about future and the role of the Georgian language in this future, if they are aware about the methods and the textbooks, which are considered appropriate for this aim and if they know the Georgian teachers at school, and even give their children advices about learning, then more 
OF PSYCHOLOGY

IN THE $21^{\text {st }}$ CENTURY Volume 5, 2013

10

higher are child's marks of academic achievement in Georgian language and appropriately higher is the language competence.

We know that in the process of any kind of activity the sense of self-esteem is very important (Gardner \& Lambert, 1985; Cook, 2008; Heyde, 1979) Especially - pupil's evaluation of own skills and abilities is critical in the process of language learning (Müller \& Dittman-Domenichini, 2008). The pupil's anxiety related with usage of the second language in several situations plays significant role in the process of second language acquisition (Bailey, 1983; MacIntyre \& Gardner, 1989). If the pupil is especially concerned about failure, consequently he tries to avoid the situations, in which the probability of such negative feeling is high. For him receptiveness of the environment is the significant repercussion. If the pupil considers that assigned task exceeds his abilities, is very complex and unfeasible, then he quits learning as he is pre-determined that he can reach no results. This interpretation can explain why the language anxiety of the pupil (the situational fear of the second language usage) has predictive value for successful acquisition of the language. According to our results, the lower is the indicator of anxiety, the higher marks has pupil in Georgian language and the higher is his language competence.

\section{Conclusions}

Our research work represents very urgent and interesting theme in Georgian reality. We can conclude this from the fact that the Georgian language became the language for communication between the Georgians and ethnical minorities living in Georgia, replacing the Russian language with this function; and on the other hand, Georgian is the State Language in Georgia and education is attainable mainly in this language. Correspondingly, it became very important for the ethnical minorities to learn Georgian. Additionally, language is the best tool for any cultural integration.

The study of the psychological factors has been carried in many countries, especially in those where the problem of the second language acquisition is important in terms of national or social purposes (China, Japan, Canada and so on). Our research work is responding those researches and perhaps one more theoretical importance of it is that we can share our experience with the researchers from many other countries, receive recommendations from them for further development of our work.

As for the practical value of the research, the results of the analysis and consequent conclusions may be used for further developing of Georgian as the second language acquisition methodology and making corrections in methods of teaching.

As it was shown by the results of study, in the process of the Georgian language learning as the second language, the determinant of the success or failure is the pupil's language consciousness which implies his own and his family's attitude to the Georgians and Georgian language, and the level of comprehension the role of the Georgian language, the advantages of its acquisition for the ethnical minorities as well as generally the level of awareness about the role of the Georgian language. As it can be seen from these conclusions, training modules can be created for teachers and parents in order to increase the level of language perception.

Another predictor of success in Georgian, as second language acquisition is students' self-confidence, degree of self-trust. Training modules can be planned in this direction too.

\section{References}

Aellen, C., \& Lambert, W. E. (1969). Ethnic identification and personality adjustments of Canadian adolescents of mixed English-French parentage. Canadian Journal of Behavioral Science, 1, 69-86.

Bailey, K. M. (1983). Competitiveness and anxiety in adult second language learning: Looking at and through the diary studies. In H. Seliger \& M. Long (Eds.), Classroom oriented research in second language acquisition, 67-103. Rowley, MA: Newbury House.

Baker, S. C. (2006, June). The Psychology of the Language Learner: Individual Differences in Second Language Acquisition (Review). Retrieved from, http://muse.jhu.edu/login?auth=0\&type=summary\&url=/journals/ canadian_modern_language_review/v062/62.4baker.pdf

Clement, R., Dornyei, Z., \& Noels, K. A. (1994). Motivation, self-confidence and group cohesion in the foreign language classroom. Language Learning, 28(1), 55-68. 
Clément, R., Gardner, R. C., \& Smythe, P. C. (1980). Social and individual factors in second language acquisition. Canadian Journal of Behavioral Science, 12, 293-302.

Cook, V. (2008). Second language learning and language teaching. 4th ed. London: Hodder Arnold.

Firth, A., \& Wagner, J. (1997). On Discourse, Communication, and (Some) Fundamental Concepts in SLA Research. The Modern Language Journal, 81,285-300.

Gardner, R. C. (1960). Motivational variables in second-language acquisition. Doctoral dissertation, McGill. Retrieved from http://publish.uwo.ca/ gardner/docs/phd.pdf

Gardner, R. C., Gliksman, L., \& Smythe, P. C. (1978). Attitudes and behavior in second language acquisition: A social psychological interpretation. Canadian Psychological Review, 19, 173-186.

Gardner, R. C., \& Lambert, W. E. (1985). Language aptitude, intelligence, and second language achievement. Journal of Educational Psychology, 66 (4), 191-189.

Gardner, R. C., Tremblay, P. F. \& Masgoret, A. (1997). Towards a Full Model of Second Language Learning: An Empirical Investigation. The Modern Language Journal, Vol. 81 (3), 344-362.

Gardner, R. C. (1985). Social psychology and second-language learning. The social psychology of language. 1-201. London: Edward Arnold.

Gardner, R. C. (1985). The Attitude/Motivation Test Battery: Technical Report.

Gardner, R.C. (2007). Motivation and second language acquisition. Porta Linguarum. 8, 9-20.

Lalonde, R. N., \& Gardner, R. C. (1984). Investigating a causal model of second language acquisition: Where does personality fit? Canadian Journal of Behavioral Science, 16, 224-237.

Lalonde, R. N., \& Gardner, R. C. (1993). Statistics as a second language? A model for predicting performance in psychology students. Canadian Journal of Behavioral Science, 25, 108-125.

Lantolf, J.P. (2007). Sociocultural source of thinking and its relevance for second-language acquisition. Bilingualism: Language and Cognition 10 (1), 31-33.

MacIntyre, P. D., \& Gardner, R. C. (1989). Anxiety and second-language learning: Toward a theoretical clarification. Language Learning (A Journal of Research in Language Studies), 39 (2), 251-275.

Martos, R.M.C. (2006). Second language acquisition Psychological factors, Affective/emotional factors. La revista de educación, 9, Retrieved from, http://www.aldadis.net/revista9/documentos/07.pdf

Müller, R. \& Dittman-Domenichini, N. (2007). Die Entwicklung schulisch-standardsprachlicher Kompetenzen in der Volksschule. Eine Quasi-Längsschnittstudie. Linguistik online, 32(3). Retrieved from http://www.linguistik-online.de/32 07/muellerEtAl.html

Ortega, L. (2005). Methodology, epistemology, and ethics in instructed SLA research: An Introduction. Special Issue of the Modern Language Journal, 89(3). 317-327.

Racu, J. (2008). Language psychogenesis in mixed communication environments. Master's thesis, Chisinau Pedagogical State University.

Reynolds, A. G. \& Lambert, W. E. (1991). Bilingualism, multiculturalism, and second language learning: The McGill conference in honour of Wallace E. Lambert. Hillsdale, NJ: Lawrence Erlbaum Associates.

Advised by Aleksandr Lobanov, Belarusian State Pedagogical University, Republic of Belarus

la Aptarashvili PhD., Assistant Professor, Tbilisi State University, Tbilisi, Georgia.

E-mail: ia.aptarashvili@tsu.ge, aptarashviligmail.com.

Website: http://tsu.ge

Mzia Tsereteli Doctor of Psychological Sciences (Habilitation), Full Professor, Tbilisi State University, Tbilisi, 